\title{
The Role of MCPIP1 in Ischemia/ Reperfusion Injury-Induced HUVEC Migration and Apoptosis
}

\author{
Tiebing Zhu ${ }^{\mathrm{a}}$ Qi Yao ${ }^{\mathrm{a}}$ Xiaonan $\mathrm{Hu}^{\mathrm{b}}$ Chen Chen ${ }^{\mathrm{b}}$ Honghong Yaoc,d \\ Jie Chaob,d \\ aDepartment of Cardiology, The First Affiliated Hospital of Nanjing Medical University, Nanjing, Jiangsu, \\ bDepartment of Physiology, Medical School of Southeast University, Nanjing, Jiangsu, 'Department \\ of Pharmacology, Medical School of Southeast University, Nanjing, Jiangsu, 'Key Laboratory of \\ Developmental Genes and Human Disease, Institute of Life Sciences, Southeast University, Nanjing, \\ Jiangsu, China
}

\section{Key Words}

HUVEC • MCPIP1 • Migration • Apoptosis

\begin{abstract}
Background/Aims: Monocyte chemotactic protein-induced protein 1 (MCPIP1) plays a crucial role in various cellular processes, including neurogenesis. However, the relationship between MCPIP1 and myocardial ischemia/reperfusion (I/R) injury remained illdefined. In this study, we explored whether the I/R-mediated up-regulation of MCPIP1 is critical in the modulation of both cell migration and apoptosis in human umbilical vein endothelial cells (HUVECs). Methods: Using Western blot analysis and quantitative real-time PCR, the protein expression and mRNA transcription, respectively, of MCPIP1 was detected in HUVECs. To investigate cell migration, an in vitro scratch assay and a nested matrix model were applied. Results: I/R increased the expression of MCPIP1 via the activation of the mitogen-activated protein kinase (MAPK) and PI3K/Akt pathways. I/R increased migration and apoptosis of HUVECs, which were significantly inhibited by MCPIP1 siRNA. Conclusion: These findings suggest that I/R-mediated up-regulation of MCPIP1 regulates migration and apoptosis in HUVECs. Understanding the regulation of MCPIP1 expression and function may aid in the development of an adjunct therapeutic strategy in the treatment of individuals with I/R injury.
\end{abstract}

Copyright (C) 2015 S. Karger AG, Basel

\section{Introduction}

Cardiovascular disease is the leading cause of death in advanced and industrialized countries; ischemia/reperfusion (I/R) injury is an important aspect of cardiovascular disease [1-5]. The prevention and management of I/R injury are key steps in coronary heart disease treatment and are becoming important issues in ischemic heart disease [6, 7]. Following

Jie Chao

KARGER 125
Department of Physiology, Medical School of Southeast University,

87 Dingjiaqiao Rd, Nanjing, Jiangsu, 210009, (China)

Tel. +86-25-83272312, E-Mail chaojie@seu.edu.cn 


\section{Cellular Physiology Cell Physiol Biochem 2015;37:577-591 \begin{tabular}{l|l} 
DOI: 10.1159/000430378 & (C) 2015 S. Karger AG, Basel
\end{tabular} \begin{tabular}{l|l|} 
and Biochemistry Published online: September 01, 2015 & www.karger.com/cpb \\
\cline { 1 - 2 }
\end{tabular} \\ Zhu et al.: The Role of MCPIP1 in HUVECs Subjected to I/R}

I/R injury, the heart suffers from mitochondrial and vascular endothelial cell dysfunction, which can result in cardiac remodeling and heart failure $[8,9]$. However, the mechanisms underlying this dysfunction remain poorly understood.

Angiogenesis plays an important role in inflammatory diseases such as diabetes and ischemic heart disease [10]. In addition to their role in the production of growth factors, inflammatory mediators are also believed to play an important role in the generation of new blood vessels [11-13]. After the onset of myocardial ischemia, reperfusion occurs. Reperfusion is followed by the rapid cellular infiltration of neutrophils and monocytes and the release of several proinflammatory cytokines, which orchestrate tissue repair processes. Among these proinflammatory factors, monocyte chemotactic protein-1 (MCP-1), a key cysteine-cysteine (CC) chemokine responsible for both the trafficking and the activation of monocytes and macrophages, has been implicated in angiogenesis [14, 15]. Angiogenesis is a complex process that involves the activation and conversion of quiescent endothelial cells to migratory and proliferative phenotypes and the differentiation of endothelial cells to an angiogenic phenotype [16]. Endothelial cell apoptosis was recently implicated in the initiation of angiogenesis and the regression of neo-vessels [17-19]. Moreover, mounting evidence from in vivo studies have demonstrated that MCP-1-induced angiogenesis is mediated by either monocyte chemotaxis [15, 20-22] or the activation of the VEGF pathway and the RhoA small G protein $[23,24]$. However, the involvement of MCP-1 in the regulation of endothelial cell dysfunction and the mechanisms by which MCP-1 mediates this process remains unclear.

MCP-1-induced protein 1 (MCPIP1), a novel transcription factor, was originally identified in human monocytes treated with MCP-1 and exhibits proapoptotic activity [25, 26]. MCP-1 induces the expression of MCPIP1, which subsequently up-regulates various members of the apoptotic gene family that have been linked to angiogenesis in placental vasculogenesis and to vascular remodeling [17-19]. MPCIP1 has also been found to promote glial differentiation in NT2 neuroprogenitor cells treated with MCP-1 [26, 27]. Furthermore, MCPIP1 has been identified as a negative regulator of macrophage activation [28]. MCP-1 treatment of human umbilical vein endothelial cells (HUVECs) results in the increased expression of MCPIP1 and MCPIP1-enhanced endothelial cell apoptosis and migration [10, 26]. However, the role of MCPIP1 in the I/R-mediated regulation of the migration and apoptosis of HUVECs remains unclear.

The present study aimed to study the effect of I/R injury on the expression of MCPIP1 and to determine the mechanisms by which I/R injury mediates the increased expression of MCPIP1 in HUVECs. Furthermore, this study investigates the functional implications of I/R injury on cellular migration and apoptosis. The results and conclusions presented may aid clinicians and researchers in understanding the regulation of MCPIP1 expression and its functional relevance to I/R injury and provide insights into potential therapeutic targets in myocardial ischemia.

\section{Materials and Methods}

\section{Reagents}

Fetal bovine serum (FBS), normal goat serum, Dulbecco's modified Eagle's medium (DMEM; \#1200046), and 10X-MEM (11430-030) were all obtained from Life Technologies. Amphotericin B (BP2645) and GlutaMax Supplement (35050-061) were obtained from Gibco, and Pen Strep (15140-122) was obtained from Fisher Scientific. PureCol type I bovine collagen $(3 \mathrm{mg} / \mathrm{mL}$ ) was obtained from Advanced Biomatrix. The antibodies for p53 (SC6243, rabbit), MCPIP1 (SC136750, goat) and $\beta$-actin (SC8432, mouse) were obtained from Santa Cruz Biotechnology, Inc. The transfection reagent for the short interfering RNA (siRNA), DharmaFECT, was purchased from Thermo Scientific. HUVECs were purchase from Genomeditech.

The simulated I/R model was a modified version of a method described previously [29-31]. First, normal culture medium was replaced with serum-free DMEM before the start of the experiment. Following 


\section{Cellular Physiology Cell Physiol Biochem 2015;37:577-591 \\ \begin{tabular}{l|l} 
DOI: 10.1159/000430378 & (C) 2015 S. Karger AG, Basel
\end{tabular} \\ and Biochemistry Published online: September 01, $2015 \quad$ www.karger.com/cpb \\ Zhu et al.: The Role of MCPIP1 in HUVECs Subjected to I/R}

pregassing with $95 \% \mathrm{~N}_{2}$ and $5 \% \mathrm{CO}_{2}$ for a minimum of $5 \mathrm{~min}$, the ischemic buffer $\left(1 \mathrm{mM} \mathrm{NaH}_{2} \mathrm{PO}_{4}, 24 \mathrm{mM}\right.$ $\mathrm{NaHCO}_{3}, 2.5 \mathrm{mM} \mathrm{CaCl}_{2}, 118 \mathrm{mM} \mathrm{NaCl}, 16 \mathrm{mM} \mathrm{KCl}, 0.5 \mathrm{mM}$ sodium EDTA, $20 \mathrm{mM}$ sodium lactate, pH 6.8, $37^{\circ} \mathrm{C}$ ) was added to the cells, which were then placed in a sealed chamber containing the deoxygenation reagent, leading to the consumption of $\mathrm{O}_{2}$ and the production of $\mathrm{CO}_{2}$. This Anaero-Pack system created near-anaerobic conditions, with an $\mathrm{O}_{2}$ concentration of $<1 \%$ and a $\mathrm{CO}_{2}$ concentration of approximately $5 \%$ following $1 \mathrm{~h}$ of incubation at $37^{\circ} \mathrm{C}$ [32]. To directly determine the efficacy of the equilibrating system, the $\mathrm{PO}_{2}$ of the medium was measured directly in a few of the experiments using a phosphorescence decay method [33, 34]. The actual supernatant $\mathrm{PO}_{2}$ values were $4.5 \pm 0.3 \mathrm{~mm} \mathrm{Hg}$ (mean $\pm \mathrm{SEM}$ ). Cells in a 24-well plate were treated with an ischemic buffer solution (1 mL/well) for $2 \mathrm{~h}$ before being incubated in glucosecontaining DMEM at $37^{\circ} \mathrm{C}$ in $95 \% \mathrm{O}_{2}$ and $5 \% \mathrm{CO}_{2}$ (reperfusion) for $24 \mathrm{~h}$.

\section{Reverse transcription and real-time PCR}

Total RNA was extracted using Trizol reagent (Invitrogen, Carlsbad, CA, USA) according to the manufacturer's instructions. Total mRNA $(1 \mu \mathrm{g})$ was reverse transcribed using cDNA RT kits (Thermo, Rockford, IL, USA) according to the manufacturer's instructions. Real-time PCR was performed using SYBR Green Master Mix (SA Biosciences, Frederick, MD, USA) on an Applied Biosystems 7500 Fast Real-Time PCR System (Foster City, CA, USA). The cycle threshold (Ct) values were analyzed using the comparative Ct $(\triangle \Delta \mathrm{Ct})$ method following MIQE Guidelines. The amount of target was normalized to an endogenous reference (GAPDH) and expressed relative to a control (non-treated cells). The following oligonucleotides were used as primers for human MCPIP1: (forward, 5'-GTC TGA CGG GAT CGT GGTTT-3'; reverse, 5'- TGA GTG GCT TCT TAC GCAGG-3'); and human GAPDH: (forward, 5'- CAA TGA CCC CTT CAT TGACC-3'; reverse, 5' - TTG ATT TTG GAG GGA TCTCG -3') [35].

Lentiviral transduction of HUVECS

HUVECs were transduced with LV-RFP lentivirus (Hanbio, Inc., Shanghai, CN) as previously described $[36,37]$. Briefly, HUVECs were cultured in a 24 -well plate ( $1 \times 10^{4}$ cells/well) in $10 \%$ FBS in DMEM for 48 $\mathrm{h}$. The medium was then replaced with $1 \mathrm{~mL}$ fresh medium and $8 \mu \mathrm{g} / \mathrm{mL}$ polybrene. Fifty microliters of lentivirus solution $\left(10^{7} \mathrm{IU} / \mathrm{mL}\right)$ was added to each well, and the plates were incubated at $37^{\circ} \mathrm{C}$ and $5 \% \mathrm{CO}_{2}$ for $24 \mathrm{~h}$. Following incubation, the treatment medium was replaced with fresh $10 \%$ FBS in DMEM, and the cells were cultured at $37^{\circ} \mathrm{C}$ and $5 \% \mathrm{CO}_{2}$ until $>50 \%$ confluence was reached. The transduced cells were selected using puromycin. For selection, the medium was replaced with $10 \mu \mathrm{g} / \mathrm{mL}$ puromycin in $10 \%$ FBS in DMEM, followed by culture at $37^{\circ} \mathrm{C}$ and $5 \% \mathrm{CO}_{2}$ for $24 \mathrm{~h}$. The cells were subsequently washed twice with fresh 10\% FBS in DMEM. The pure and transduced HUVEC cultures were expanded and stored in liquid nitrogen as previously described [38].

\section{HUVEC-populated collagen matrix (HPCM)}

A collagen matrix model was utilized as previously described $[38,39]$. The final matrix parameters were as follows: volume $=0.2 \mathrm{~mL}$; diameter $=12 \mathrm{~mm}$; collagen concentration $=1.5 \mathrm{mg} / \mathrm{mL}$; and cell concentration $=1.0 \times 10^{6}$ cells $/ \mathrm{mL}$. The matrices were established in 24-well plates (BD\#353047) and were incubated in the attached state with 5\% FBS in DMEM (supplemented with $50 \mu \mathrm{g} / \mathrm{mL}$ ascorbic acid) for approximately $48 \mathrm{~h}$ prior to the initiation of the experiments.

\section{Knockdown of MCPIP1 using siRNA in CPCM}

Knockdown of MCPIP1 was performed on HPCMs as previously described [40] with some modifications. The protocol for a single collagen matrix was as follows: $17.5 \mu \mathrm{L}$ serum-free DMEM was combined with $3 \mu \mathrm{L}$ transfection reagent and $3 \mu \mathrm{L}$ siRNA stock, separately, followed by incubation at room temperature (RT) for $15 \mathrm{~min}$. The transfection reagent and the siRNA solutions were mixed together and incubated at RT for an additional $15 \mathrm{~min}$. Meanwhile, HUVECs were prepared according to the HPCM protocol at a concentration of $5.0 \times 10^{6}$ cells $/ \mathrm{mL}$ in serum-free DMEM. The siRNA-vehicle solution was mixed with $40 \mu \mathrm{L}$ cell suspension and incubated at RT for $15 \mathrm{~min}$. The cell/siRNA/vehicle solution was added during the HPCM setup. The transfected matrices were cultured in serum-free DMEM for $24 \mathrm{~h}$, after which the medium was replaced with $10 \%$ FBS in DMEM for $48 \mathrm{~h}$ prior to additional experiments. The knockdown efficiency of the siRNAs was determined via Western blot after 2 days of transfection. 


\section{Cellular Physiology Cell Physiol Biochem 2015;37:577-591 \begin{tabular}{l|l}
\hline DOI: 10.1159/000430378 & (c) 2015 S. Karger AG, Basel
\end{tabular} and Biochemistry Published online: September 01, 2015 www.karger.com/cpb \\ Zhu et al.: The Role of MCPIP1 in HUVECs Subjected to I/R}

In vitro scratch assay

Cell migration in a 2D culture system was evaluated using an in vitro scratch assay. Briefly, $1 \times 10^{5}$ HUVECs were seeded into 24-well tissue culture plates and cultured in growth medium for $24 \mathrm{~h}$ until approximately $70-80 \%$ confluence. Using a sterile $200 \mu \mathrm{L}$ pipette tip, a straight line was carefully scratched into the monolayer across the center of the well in a single direction; the tip remained perpendicular to the plate bottom throughout this process. Similarly, a second straight line was scratched perpendicular to the first line to create a cross-shaped cellular gap in each well. Each well was washed twice with $1 \mathrm{~mL}$ of fresh growth medium to remove any detached cells. Digital images of the cell gaps were captured at different timepoints, and the gap widths were quantitatively evaluated using ImageJ software.

\section{Nested matrix model and cell migration}

A nested collagen matrix model was utilized as previously described [37, 41, 42] with some modifications. For the nested attached matrix, a standard CPCM was incubated in the attached state for $72 \mathrm{~h}$ with 10\% FBS in DMEM; the CPCM was subsequently removed from the culture well and placed into a $60 \mu \mathrm{L}$ aliquot of fresh acellular collagen matrix solution (neomatrix solution) centered inside a 12-mm diameter score on the bottom of a new culture well. A $140 \mu \mathrm{L}$ aliquot of neomatrix solution was then used to cover the newly transferred CPCM. The neomatrix was allowed to polymerize for $1 \mathrm{~h}$ at $37^{\circ} \mathrm{C}$ and $5 \% \mathrm{CO}_{2} ; 2 \mathrm{~mL}$ of DMEM with $10 \%$ FBS was subsequently added to the well.

Cell migration out of the nested FPCM and into the acellular neomatrix was quantified $24 \mathrm{~h}$ following nesting using fluorescence microscopy. Digital images $(1000 \times 800 \mu \mathrm{m})$ were captured using an EVOS FL Cell Imaging microscope (Life Technologies, Grand Island, NY) from 3-5 randomly-selected microscopic fields at the interface of the nested CPCM with the acellular neomatrix. HUVEC migration out of the nested CPCM was quantified by counting the number of cells that had migrated from the nested matrix into the cell-free matrix. The maximum migration distance of the cells was also quantified by counting the cells that migrated the furthest from the nested matrix into the cell-free matrix using ImageJ software. The number of cells that had migrated out of the nested matrix and the maximum migration distance per field were averaged using these digital micrographs.

\section{Immunoblotting}

Immunoblotting was utilized as previously described [38] with minor modifications. The cells were washed with PBS and lysed using a Mammalian Cell Lysis kit (MCL1-1KT, Sigma-Aldrich) according to the manufacturer's instructions. Western blots were probed using different antibodies. The secondary antibodies were either goat anti-mouse or anti-rabbit IgG antibodies conjugated to alkaline phosphatase (1:5000). The signals were detected via chemiluminescence (SuperSignal West Dura Chemiluminescent Substrate, Thermo Scientific). Each Western blot was repeated in three different experiments. A single representative immunoblot for all related blots is presented in each figure. Densitometry was performed using ImageJ software (http://rsb.info.nih.gov/ij/), and the results for each of the repeated experiments were combined into one plot.

\section{MTT assay}

Cell viability was measured via the 3-(4,5-dmethylthiazol-2-yl)-2,5-diphenyl tetrazolium bromide (MTT) method [36]. Briefly, cells were collected and seeded into 96-well plates. Different seeding densities were optimized at the beginning of the experiments. The cells were exposed to the I/R medium. Following incubation for different time periods (3-24 h), $20 \mu \mathrm{L}$ of MTT tetrazolium salt dissolved in Hank's balanced salt solution was added to each well at a final concentration of $5 \mu \mathrm{g} / \mathrm{mL}$, and the plates were incubated in a $\mathrm{CO}_{2}$ incubator for 1-4 h. Finally, the medium was aspirated from each well, and $200 \mu \mathrm{L}$ of dimethyl sulfoxide was added to dissolve the formazan crystals. The absorbance of each well was obtained using a microtiter plate spectrophotometer and reference wavelengths of $570 \mathrm{~nm}$ and $630 \mathrm{~nm}$. Each of the experiments was repeated at least three times.

\section{Hoechst staining}

To quantify the number of apoptotic cells, the cells were fixed and stained with $5 \mu \mathrm{M}$ Hoechst 33324 (Invitrogen) for $15 \mathrm{~min}$ at room temperature [35]. The morphological features of apoptosis (cell shrinkage, chromatin condensation, and fragmentation) were monitored using fluorescence microscopy (Nikon TE2000E microscope). 


\begin{tabular}{|c|c|c|}
\hline Cellular Physiology & Cell Physiol Biochem 2015;37:577-591 & \\
\hline and Biochemistry & $\begin{array}{l}\text { DOI: 10.1159/000430378 } \\
\text { Published online: September 01, } 2015\end{array}$ & $\begin{array}{l}\text { O } 2015 \text { S. Karger AG, Basel } \\
\text { www.karger.com/cpb }\end{array}$ \\
\hline
\end{tabular}

Terminal deoxynucleotidyl transferase-mediated biotinylated UTP nick end labeling staining (TUNEL) assay

TMR Red (Roche), an in situ cell death detection kit, was used to label apoptotic cells according to the manufacturer's instructions as described previously [43, 44]. Briefly, HUVECs subjected to I/R were fixed for 30 min with $4 \%$ paraformaldehyde at RT. The fixed cells were then permeabilized using $1 \%$ Triton X-100 for $30 \mathrm{~min}$, followed by staining with a terminal deoxynucleotidyl transferase-mediated biotinylated UTP nick end labeling (TUNEL) reaction mixture for $60 \mathrm{~min}$ according to the manufacturer's instructions (Roche).

\section{Statistics}

Data are expressed as the means \pm SEMs. Unpaired numerical data were compared using either an unpaired t-test (two groups) or ANOVA (more than two groups); significance was set at p $<0.05$.

\section{Results}

I/R-mediated up-regulation of MCPIP1 in HUVECS

MCP-1 is well-documented to play a crucial role in the pathogenesis of I/R [10, 11, 45]. As MCP-1 is known to induce the expression of MCPIP1, we examined the effect of I/R on the expression of MCPIP1. As shown in Fig. 1A-B, I/R treatment of HUVECs resulted in a two-fold induction of MCPIP1 expression compared with the control cells. Given that I/R exposure induced the expression of MCPIP1 at the protein level, we next examined the effect of I/R on the transcription of MCPIP1 mRNA. As shown in Fig. 1C, I/R exposure induced MCPIP1 transcription. Collectively, these data demonstrate that I/R mediates the induction of MCPIP1 expression in HUVECs.

\section{I/R-mediated activation of the MAPK (ERK, JNK, $p 38$ ) and PI3K/Akt pathways}

Because the MAPK kinase [1,6] and PI3K/Akt [46] pathways play crucial roles in I/Rmediated signaling, we next examined the involvement of these pathways in the I/R-mediated induction of MCPIP1. First, we examined the effect of I/R on the activation of MAPKs. As shown in Fig. 2A-F, the exposure of HUVECs to I/R resulted in the increased phosphorylation of both ERK and JNK with a peak response at $30 \mathrm{~min}$, whereas I/R induced the transient

Fig. 1. I/R-induced MCPIP1 expression in HUVECs. (A) Representative blots demonstrating that I/R induced MCPIP1 expression in a time-dependent manner. (B) Densitometric analyses of MCPIP1 from four separate experiments. ${ }^{*} \mathrm{p}<0.05$ vs. the 0 h group. (C). I/R induced MCPIP1 mRNA transcription in a time-dependent manner. Gene expression was examined via real-time RT-PCR with gene-specific primers. Relative fold changes compared with the control group were calculated with a CT value. $* \mathrm{p}<0.05$ vs. the $0 \mathrm{~h}$ group.

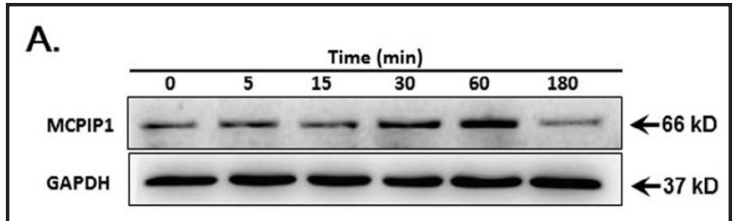

B.

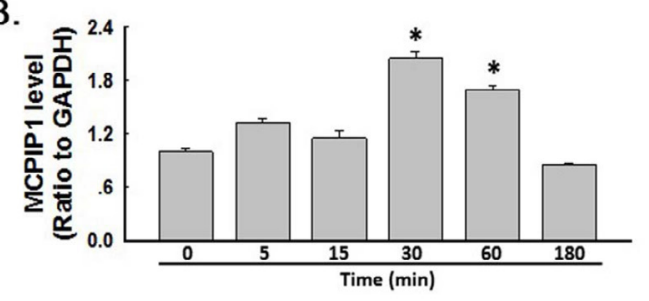

C.

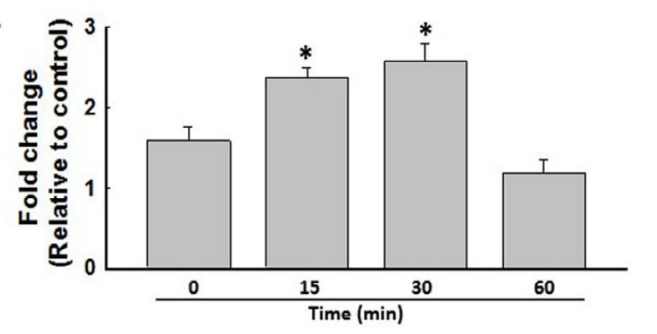




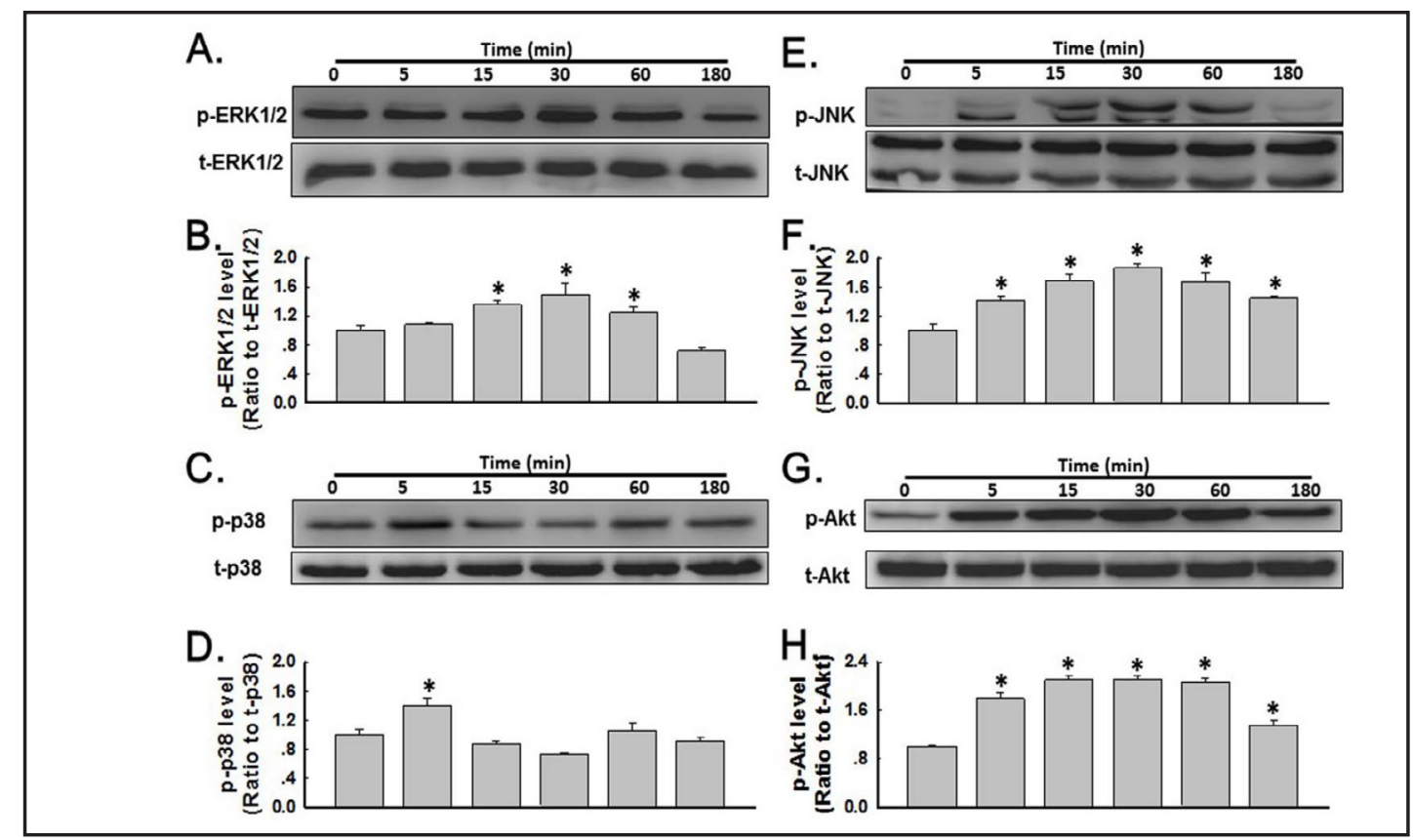

Fig. 2. I/R induced MAPK pathway and PI3K/Akt pathway activation in HUVECs. Representative blots demonstrating I/R-induced phosphorylation of ERK1/2 (A), p-38 (C), JNK (E) and Akt (G) in a time-dependent manner. Densitometric analyses of ERK1/2 (B), p-38 (D), JNK (F) and Akt (H) from four separate experiments are presented.

phosphorylation of $\mathrm{p} 38$ at $5 \mathrm{~min}$. In addition to the induction of the MAPK pathways, I/R also induced a sustained phosphorylation of Akt for 5-180 min (Fig. 2G-H).

Involvement of the MAPK (ERK, JNK, p38) and the PI3K/Akt pathways in I/R-induced MCPIP1 expression

We next attempted to determine the functional role of the MAPK and PI3K/Akt pathways in MCPIP1 expression induced by I/R. HUVECs were pretreated with inhibitors specific for the respective signaling pathways prior to stimulation with I/R, and MCPIP1 expression was subsequently assessed. As shown in Fig. 3A-B, the pretreatment of the cells with MEK (U0126, $10 \mu \mathrm{M})$, JNK (SP600125, $10 \mu \mathrm{M})$, p38 (SB203580, $10 \mu \mathrm{M})$ and PI3K (LY294002, $5 \mu \mathrm{M})$ inhibitors resulted in the amelioration of the I/R-mediated induction of MCPIP1. Together, these findings suggested the involvement of the ERK, JNK, p38 and PI3K/Akt pathways in the I/R-mediated induction of MCPIP1 in HUVECs.

Involvement of MCPIP1 in I/R-mediated migration of HUVECs in 2-D cell culture

Endothelial cell migration is a critical component of angiogenesis [10]; therefore, we next determined the role of MCPIP1 in I/R-mediated migration. Using a scratch wound healing assay, we determined that HUVEC migration increased following exposure to I/R (Fig. 4A-B).

Because proline-rich tyrosine kinase 2 (Pyk2) is involved in cell migration $[47,48]$, we next examined the effect of I/R exposure on this cell signaling pathway. Interestingly, the exposure of HUVECs to I/R induced the activation of Pyk2 with a peak response at $5 \mathrm{~min}$ (Fig. 4C-D). The transfection of the cells with Pyk2 siRNA resulted in the inhibition of the I/R-mediated induction of HUVEC migration (Fig. 4E), which was indicative of a role of Pyk2 in this process. Moreover, the transfection of MCPIP1 siRNA inhibited the phosphorylation of Pyk2 induced by I/R, as shown in Fig. 4F-G. In addition, the transfection of the cells with MCPIP1 siRNA resulted in the inhibition of the I/R-mediated induction of HUVEC migration (Fig. 4H-I), further supporting the role of MCPIP1 in this process. 


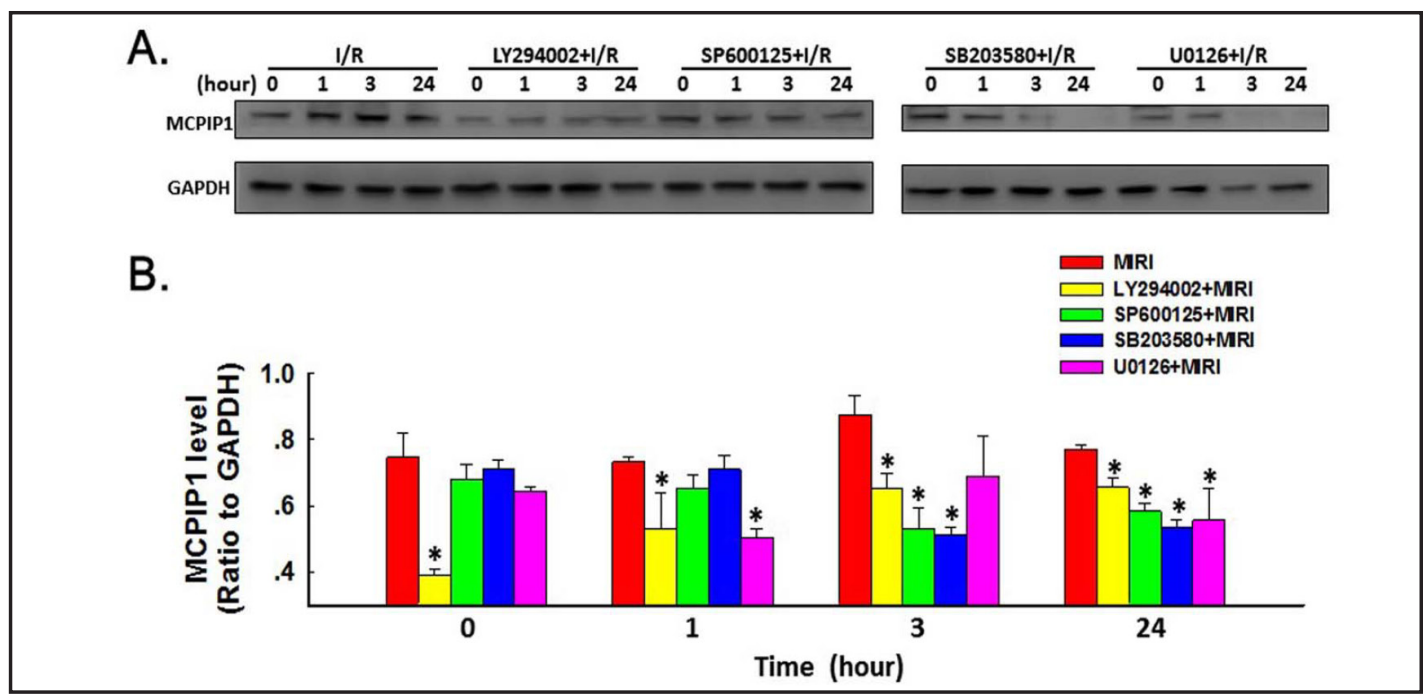

Fig. 3. Inhibition of the MAPK and PI3K/Akt pathways attenuated I/R-induced MCPIP1 expression. (A) Representative blots demonstrating that I/R-induced MCPIP1 expression was attenuated via pretreatment with LY294002 (Akt inhibitor), SP600125 (JNK inhibitor), SB203580 (p-38 inhibitor) and U0126 (ERK inhibitor). (B) Densitometric analyses of MCPIP1 from four separate experiments. ${ }^{*} \mathrm{p}<0.05$ vs. the corresponding timepoint in the I/R group.

Involvement of MCPIP1 in the I/R-mediated migration of HUVECs in 3-D cell culture

Given that that I/R exposure induced the migration of HUVECs in a 2-D cell culture system, we attempted to validate these findings by monitoring HUVEC migration in 3-dimensional (3-D) cell culture systems, which have been used for endothelial cell functional investigations $[49,50]$. As shown in Fig. 5A, increased migration was observed in response to I/R with respect to the number of migrating cells (Fig. 5B) and the increased maximal migration distance (Fig. 5C). Similarly, we examined the role of MCPIP1 in the cellular migration of HUVECs in a 3-D cell culture system. As shown in Fig. 5D-F, the transfection of HUVECs with MCPIP1 siRNA significantly inhibited the cell migration induced by I/R as determined by the number of migrated cells and the migration distance compared with the control group.

\section{Involvement of MCPIP1 in I/R-mediated apoptosis of HUVECS}

Because MCPIP1 expression increased following the exposure of HUVECs to I/R, we next attempted to determine the role of MCPIP1 in the viability of HUVECs subjected to I/R. The exposure of HUVECs to I/R resulted in significantly decreased cell viability in a timedependent manner, as shown in Fig. 6A. We next used RNA interference to determine the role of MCPIP1 in the decreased cell viability. As shown in Fig. 6B, MCPIP1 siRNA significantly inhibited the decreased viability of HUVECs subjected to I/R as determined with an MTT assay.

This finding was confirmed via cellular staining with Hoechst 33342, a nuclear dye that specifically stains nuclei. The HUVECs in the control group were characterized by regular and round nuclei (Fig. 6C-D). In contrast, condensation and fragmentation of nuclei characteristic of apoptotic cells were evident in the HUVECs subjected to I/R for $24 \mathrm{~h}$. The transfection of the HUVECs with MCPIP1 siRNA significantly ameliorated the cell death induced by I/R, as shown in Fig. 6E.

To corroborate the above findings, TUNEL staining demonstrated that $25.8 \%$ of the cells subjected to I/R were TUNEL positive at $24 \mathrm{~h}$ (Fig. 6F-G). This increased cell death was significantly ameliorated among the cells transfected with MCPIP1 siRNA (Fig. 6H). The findings in Fig. 6 suggest that MCPIP1 mediated an I/R-induced decrease in HUVEC viability. 
A.
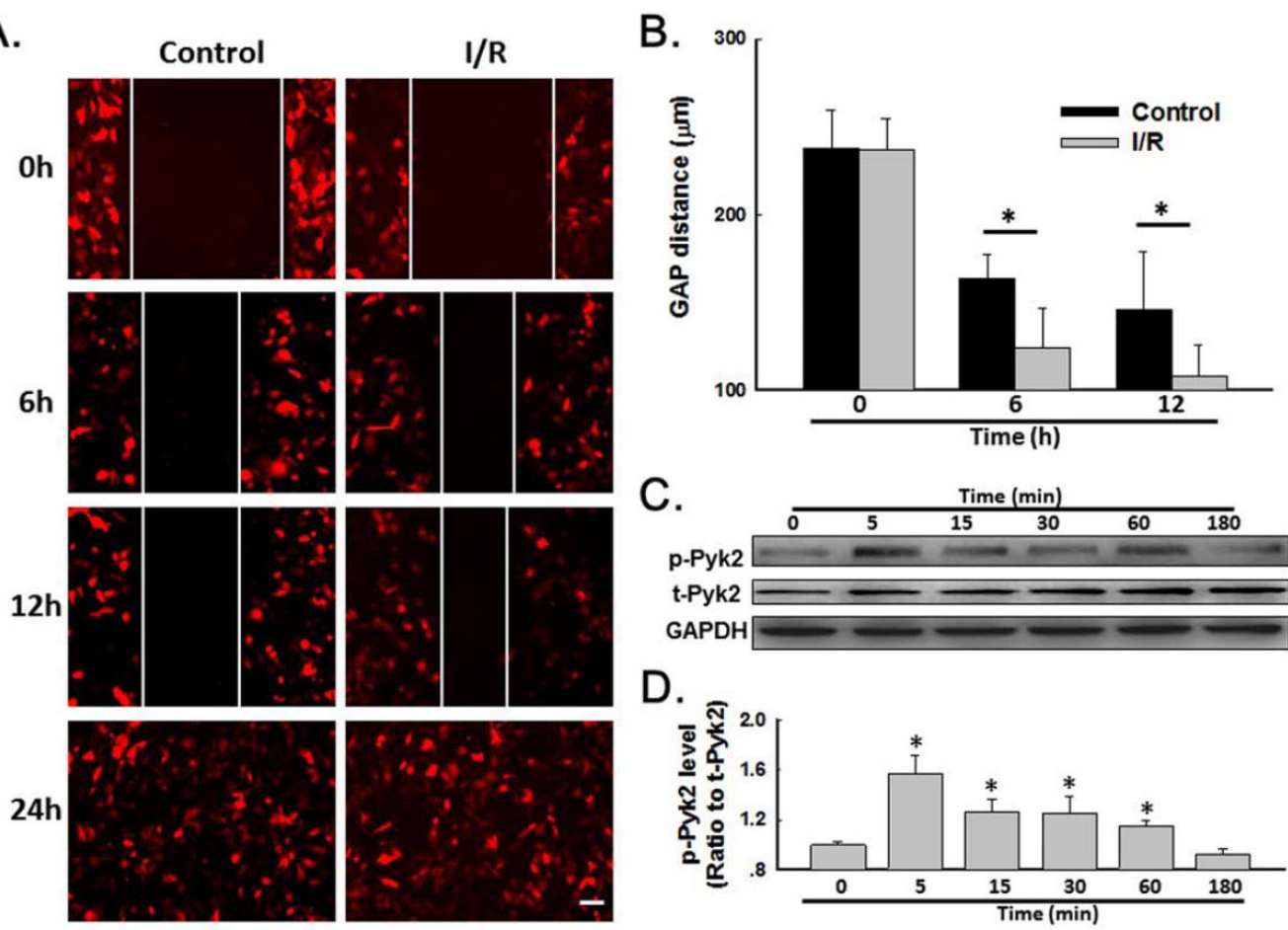

C.

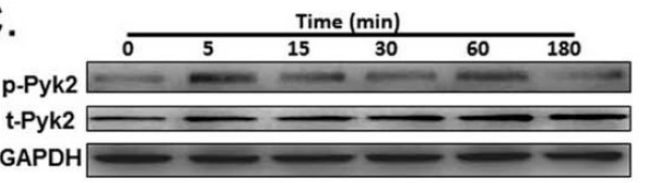

D.

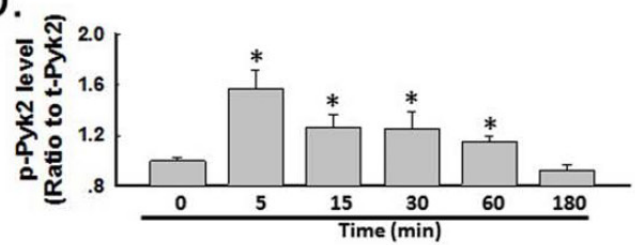

E.

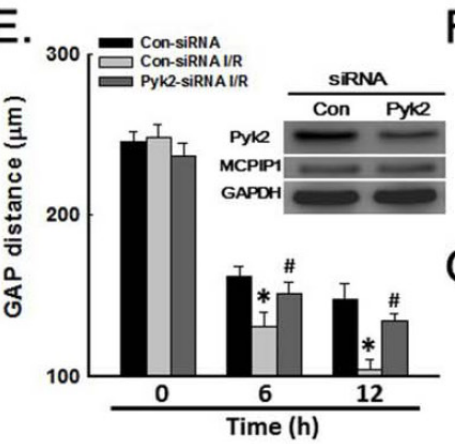

F.
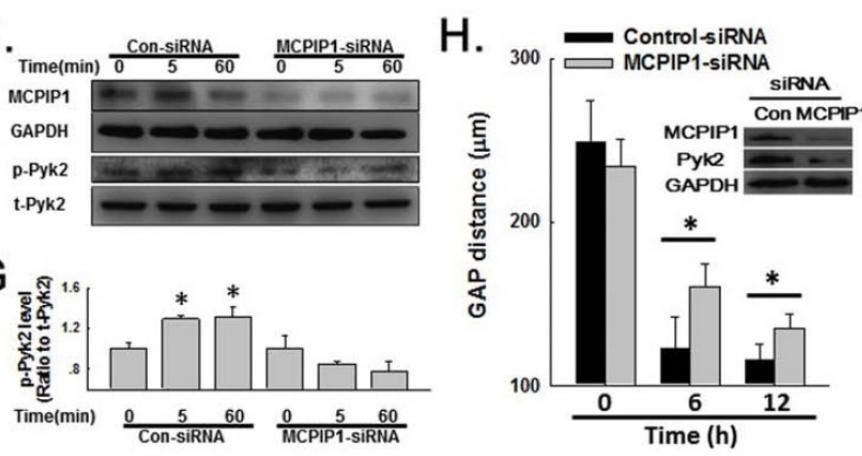

I.

(hour) Oh

$6 \mathrm{~h}$

$12 \mathrm{~h}$

24h
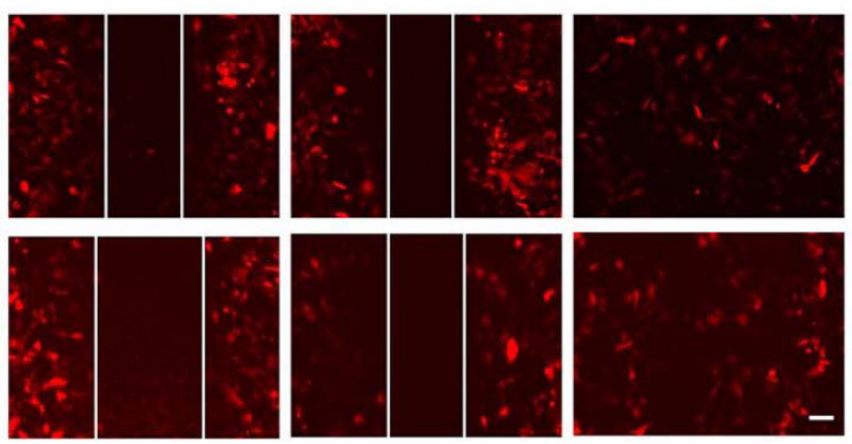

Fig. 4. MCPIP1-mediated I/R-induced HUVEC migration. (A) Representative images depicting I/R-induced cell migration in monolayer cultured HUVECs. Scale bar $=80 \mu \mathrm{m}$ (B) The quantification of the scratch gap distance from six separate experiments is presented. $* \mathrm{p}<0.05$ vs. the corresponding time point of the control group. (C) Representative blots depicting the I/R-induced phosphorylation of Pyk2 in a time-dependent manner. (D) Densitometric analyses of p-Pyk2 from four separate experiments. ${ }^{*} \mathrm{p}<0.05$ vs. the $0 \mathrm{~h}$ group. 


\section{Cellular Physiology Cell Physiol Biochem 2015;37:577-591

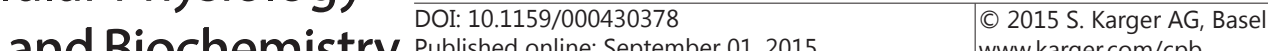 \\ and BiOchemistry Published online: September 01, $2015 \quad$ www.karger.com/cpb \\ Zhu et al.: The Role of MCPIP1 in HUVECs Subjected to I/R}

(E) Pyk2 siRNA, but not nonsense siRNA, reversed the I/R-mediated increase in cell migration in the 2D model. Small panel showed efficiency of siRNA of Pyk2. The effect of Pyk2 siRNA on expression of MCPIP1 was also provided. ${ }^{*} \mathrm{p}<0.05$ vs. the corresponding time point of the nonsense siRNA group. \# $\mathrm{p}<0.05$ vs. the corresponding I/R time point of the nonsense siRNA group. (F) Representative blots demonstrating that MCPIP1 siRNA, but not nonsense siRNA, attenuated the IR-induced increased expression of MCPIP1 and p-Pyk2. (G) Densitometric analyses of p-Pyk2 from four separate experiments. * $p<0.05$ vs. the corresponding 0 time point. $(\mathrm{H})$ The quantification of the scratch gap distance from six separate experiments is presented. Small panel showed efficiency of siRNA of MCPIP1. ${ }^{*} p<0.05$ vs. the corresponding time point of the nonsense siRNA group. (I) The representative images demonstrating that MCPIP1 siRNA, but not nonsense siRNA, attenuated the IR-induced increased cell migration of HUVECs. Scale bar $=80 \mu \mathrm{m}$. Con-siRNA: control siRNA; Con-siRNA I/R: control siRNA of I/R group; Pyk2-siRNA I/R: Pyk2 siRNA of I/R group.

\section{Discussion}

Myocardial ischemia is a common antecedent event that predisposes patients to congestive heart failure [51]. The loss of cardiacfunction following myocardial ischemia occurs in the setting of myocyte death and interstitial fibrosis, processes collectively referred to as ventricular remodeling [52]. Recent studies have demonstrated that inflammatory responses may cause myocardial damage and fibrosis, resulting in a progressive impairment of cardiac function [53]. Abnormalities of the microvasculature, including impaired angiogenesis, are important contributors to the pathogenesis of various heart diseases, including myocardial infarction and post-infarct remodeling [54]. The enhancement of angiogenic processes and the establishment of collateral circulation likely would be helpful in the setting of ischemic myocardial disease $[2,3,55,56]$.

MCP-1 facilitates angiogenesis [15, 20-22]. MCP-1 has been shown to play an important role in the development of vascular inflammation and endothelial dysfunction in the setting of I/R. In the present study, we demonstrated that the exposure of HUVECs to I/R results in the induction of MCPIP1. To delve deeper into the molecular mechanisms of the I/Rmediated induction of MCPIP1 expression, the roles of the MAPK and PI3K/Akt intercellular pathways were assessed. Using a pharmacological approach, we examined the activation of the MAPK and PI3K/Akt pathways in the setting of I/R-mediated induction of MCPIP1. Our findings are consistent with those of previous reports with respect to the role of these signaling pathways in the induction of MCPIP1 [35].

The functional significance of I/R-induced MCPIP1 was examined in an in vitro model of cell migration. The exposure of HUVECs to I/R resulted in the increased migration of HUVECs. This effect was significantly inhibited via the transfection of cells with MCPIP1 siRNA, thereby highlighting the role of MCPIP1 in I/R-induced cell migration in both 2D and 3D cell migration systems. Three-dimensional culture systems have been widely used in endothelial cell functional investigation, in which endothelial cells have shown differential responses to stimuli compared with conventional 2D culture systems [57, 58]. Increasing evidence suggests that 3D culture systems have morphologic and physiologic similarities to physiological environments [59-62]. The activation of the cytoskeletal contractile machinery is critical for cell motility [63]. The contractile force is generated via actin-myosin binding triggered by the phosphorylation of Pyk2 [48]. Pyk2, a member of the focal adhesion kinase (FAK) non-receptor tyrosine kinase family, is a cytoplasmic tyrosine kinase that regulates cell adhesion, migration and invasion $[64,65]$. The exposure of HUVECs to I/R induced the activation of Pyk2, which is consistent with these findings. The I/R-induced migration of HUVECs was significantly inhibited by transfection with Pyk2 siRNA.

In addition to cell migration, cell apoptosis was implicated in the initiation of angiogenesis. Interestingly, the exposure of HUVECs to I/R induced apoptosis, which was also significantly inhibited by MCPIP1 siRNA. This finding is consistent with that of a previous study in which MCPIP1 enhanced cell apoptosis [25, 26]. Although mounting evidence indicates that MCPIP1 was involved in the enhancement of cellular apoptosis, the previous study failed to determine the role of MCPIP1 in apoptosis in neural stem cells (NSCs). These findings lead 
A.

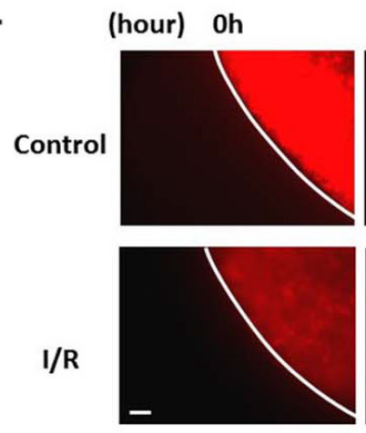

$6 h$
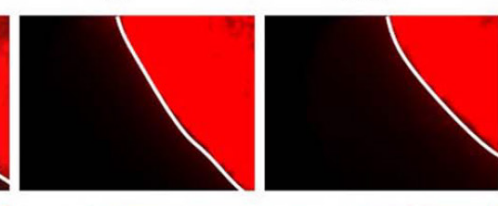

$24 \mathrm{~h}$
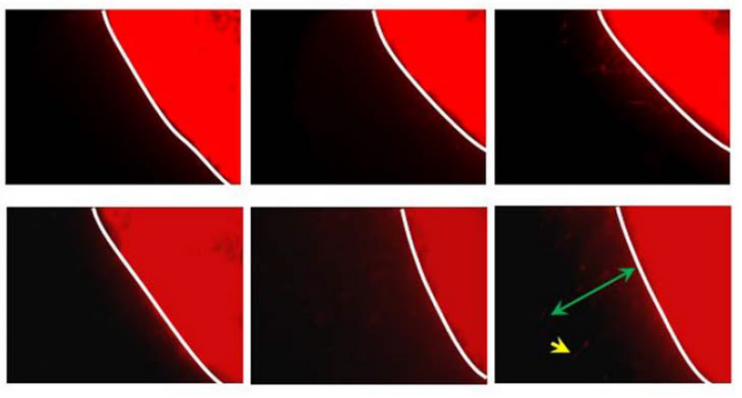

B.

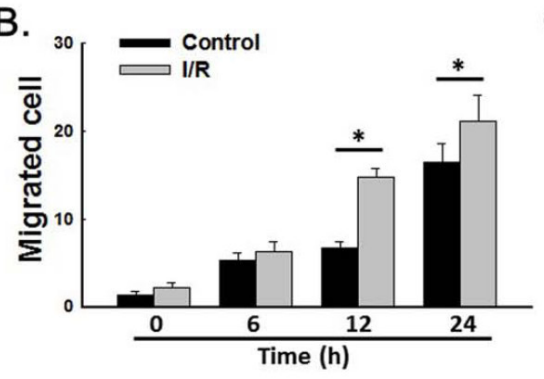

C. ${ }_{240}$ Control

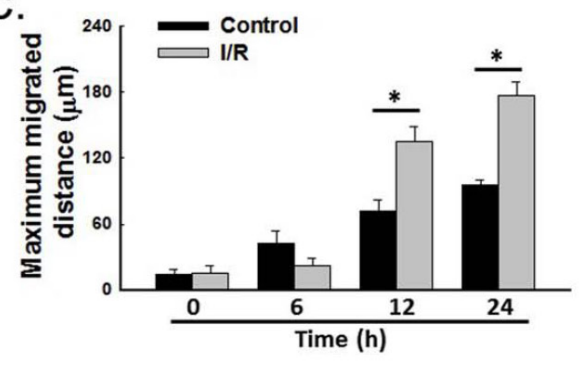

D.

(hour) oh

$6 \mathrm{~h}$ $12 \mathrm{~h}$ 24h
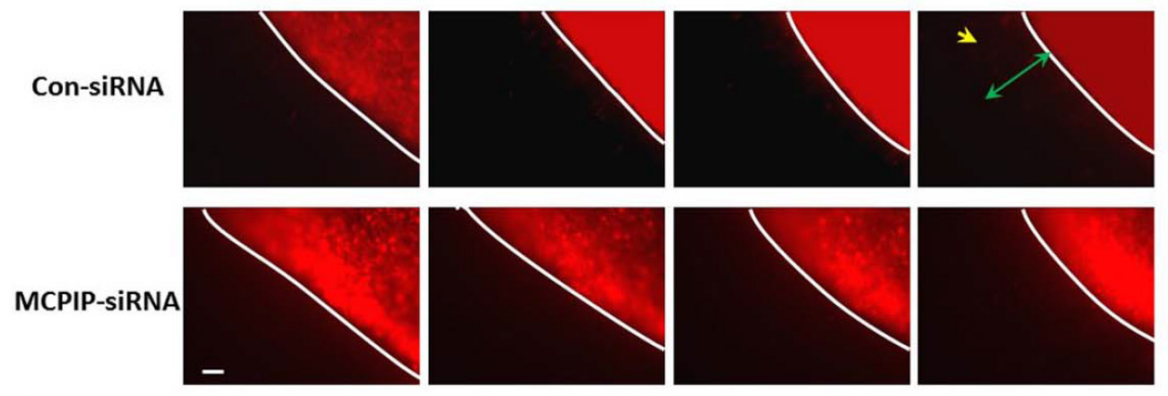

E.

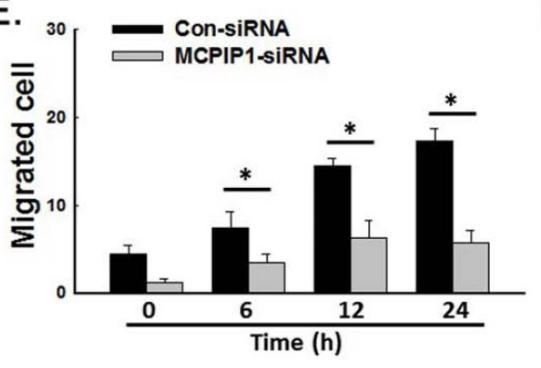

$\mathrm{F}$.

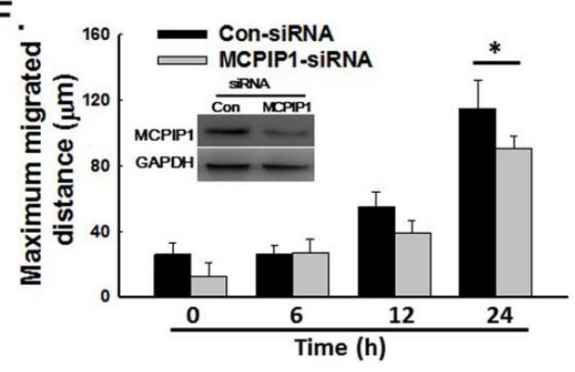

Fig. 5. MCPIP1 mediates I/R-induced HUVEC migration in a nested matrix model. (A) Representative images depicting the I/R-induced HUVEC migration in a nested matrix model. Scale bar $=80 \mu \mathrm{m}$ (B) The number of migrating cells from the nest gel in six separate experiments is presented. ${ }^{*} \mathrm{p}<0.05$ vs. the corresponding time point of the control group. (C) The quantification of the maximum migration distance from the nest gel of six separate experiments is presented. ${ }^{*} p<0.05$ vs. the corresponding time point of the control group. (D) Representative images demonstrating that MCPIP1 siRNA, but not nonsense siRNA, attenuated the I/R-induced HUVEC migration in a nested matrix model. Scale bar $=80 \mu \mathrm{m}$ (E) The number of migrating cells in the nest gel was quantified in six separate experiments. ${ }^{*} \mathrm{p}<0.05$ vs. the corresponding time point of the control group. (F) Small panel showed efficiency of siRNA of MCPIP1. The quantification of the maximum migration distance from the nest gel of six separate experiments is presented. ${ }^{*} p<0.05$ vs. the corresponding time point of the nonsense siRNA group. 


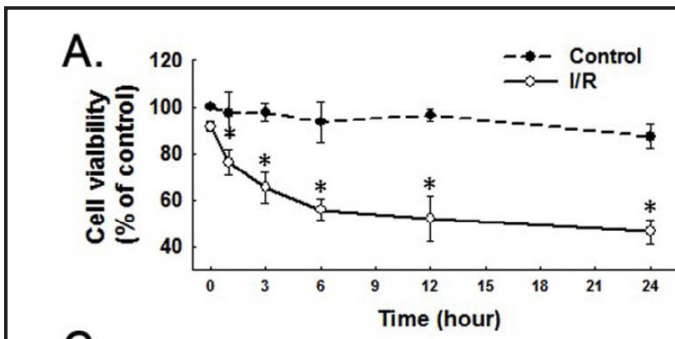

C.
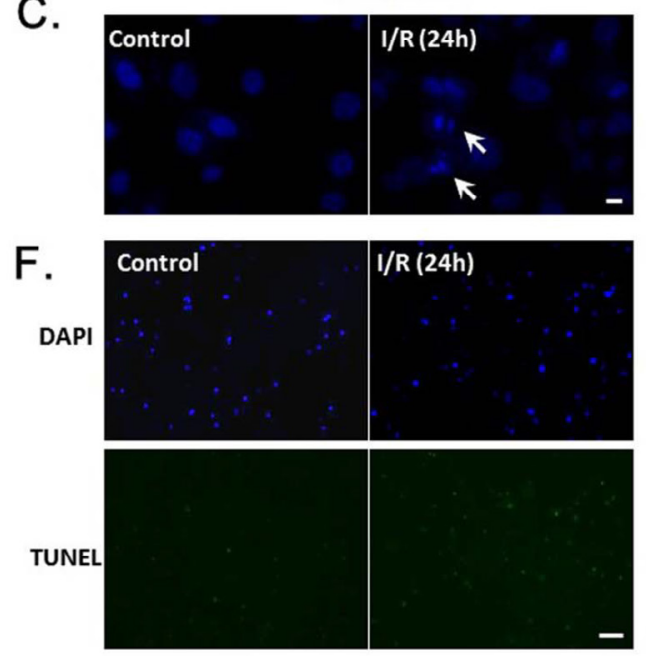

B.

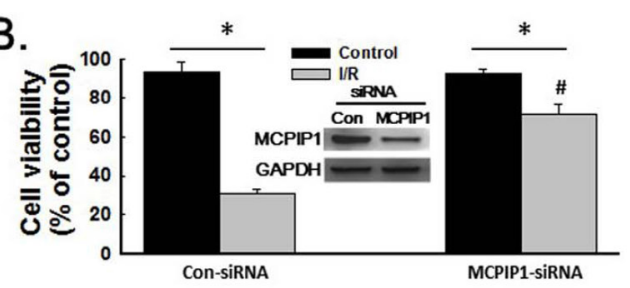

E.
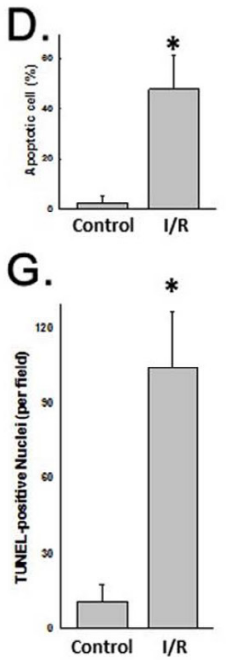

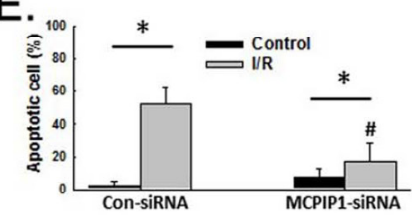

$\mathrm{H}$.

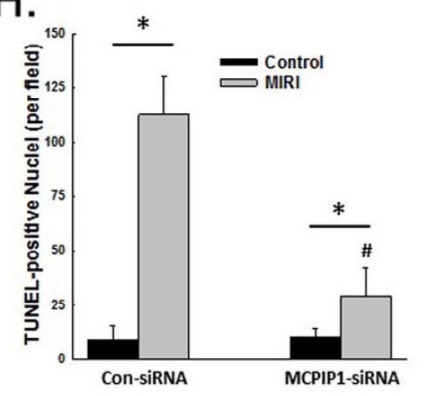

Fig. 6. MCPIP1 mediates I/R-induced cell survival. (A) I/R decreased HUVEC viability in a time-dependent manner with MTT assay. $\mathrm{p}<0.05$ vs. the corresponding time point of the control group. (B) MCPIP1 siRNA, but not nonsense siRNA, rescued HUVEC survival following $24 \mathrm{~h}$ of I/R in a nested matrix model. Small panel showed efficiency of siRNA of MCPIP1. ${ }^{*}$ p $<0.05$ vs. the corresponding time point of the control group. \# $\mathrm{p}<0.05$ vs. the corresponding I/R time point of the nonsense siRNA group. (C) Representative images of Hoechst 33342 staining depicting apoptosis of HUVECs after $24 \mathrm{~h}$ of I/R. Scale bar $=5 \mu \mathrm{m}$ (D) The percentages of apoptotic cells from six separate experiments are presented. ${ }^{*} p<0.05$ vs. the control group. (E) MCPIP1 siRNA but not nonsense siRNA attenuated I/R-induced apoptosis in the HUVECs. * $p<0.05$ vs. the corresponding time point of the control group. \# $\mathrm{p}<0.05 \mathrm{vs}$. the corresponding I/R time point of the nonsense siRNA group. (F) Representative pictures of TUNEL staining depicting HUVEC apoptosis after $24 \mathrm{~h}$ of I/R. Scale bar $=80 \mu \mathrm{m}(\mathrm{G})$ The number of apoptotic cells per field from six separate experiments is presented. *p $<0.05$ vs. the control group. (H) MCPIP1 siRNA, but not nonsense siRNA, attenuated I/R-induced HUVEC apoptosis. ${ }^{*} \mathrm{p}<0.05$ vs. the corresponding time point of the control group. $\# \mathrm{p}<0.05$ vs. the corresponding I/R time point of the nonsense siRNA group.

us to suggest that the novel transcription factor, MCPIP1, may be critical in the regulation of multiple biological processes in the same cell type and may also exhibit additional functions in other cell types. However, the HUVECs used in the current study were from a cell line that may not necessarily represent the physiological behavior and biology of endothelial cells from the arteries of aged individuals. Vascular endothelial dysfunctions have been shown to correlate with aging [66]. Further investigations are required to determine the effect of aging on endothelial function in I/R.

An interesting finding in the current study was that I/R induced HUVEC apoptosis and migration, which seem to be opposing effects. Mounting evidence suggests that angiogenesis is a complex process that involves endothelial cell activation, proliferation, migration, and apoptosis [16-19]. This may due to the role of those functions at different time intervals after I/R. As shown in Fig. 6A, a significant decrease in cell viability occurred within $6 \mathrm{~h}$ of $\mathrm{I} / \mathrm{R}$ and reached a stable state after $12 \mathrm{~h}$ of $\mathrm{I} / \mathrm{R}$, which indicated a role of apoptosis in the early stage of I/R. The migration of HUVECs started $6 \mathrm{~h}$ after I/R. These findings revealed the multifunctional capacity of MCPIP1 in HUVECs after I/R. 


\section{Cellular Physiology Cell Physiol Biochem 2015;37:577-591 \begin{tabular}{l|l} 
DOI: 10.1159/000430378 & (c) 2015 S. Karger AG, Basel
\end{tabular} www.karger.com/cpb \\ Zhu et al.: The Role of MCPIP1 in HUVECs Subjected to I/R}

In summary, our findings have identified a molecular pathway that activates the MAPK and PI3K/Akt pathways in response to IR, ultimately resulting in increased MCP1P expression. Furthermore, the I/R-mediated expression of MCPIP1 played a vital role in cell migration and apoptosis, resulting in increased angiogenesis and apoptosis during the late stages of I/R. These findings have implications for I/R among individuals with heart failure. Understanding the regulation of MCPIP1 expression and function may aid in the development of adjunct therapeutic strategies in the treatment of individuals with I/R.

\section{Acknowledgements}

This study was partially supported by the resources and the facilities of the core lab of the Medical School of Southeast University. The authors would like to acknowledge the technical assistance of Xingang Wang. BTZ was supported by grants from the Natural Science Foundation of Jiangsu Province, China (No. BK20141497). JC was supported by grants from the National Natural Science Foundation of China (81473263) and the Natural Science Foundation of Jiangsu Province, China (No. BK20141347).

\section{Disclosure Statement}

The authors have no competing financial interests to disclose.

\section{References}

1 Liu Y, Yang H, Song L, Li N, Han QY, Tian C, Gao E, Du J, Xia YL, Li HH: Aggf1 protects from myocardial ischemia/reperfusion injury by regulating myocardial apoptosis and angiogenesis. Apoptosis 2014;19:1254-1268.

2 Altamirano F, Wang ZV, Hill JA: Cardioprotection in ischemia/reperfusion injury: Novel mechanisms and clinical translation. J Physiol DOI: 10.1113/JP270953.

3 Song MA, Paradis AN, Gay MS, Shin J, Zhang L: Differential expression of micrornas in ischemic heart disease. Drug Discov Today 2015;20:223-235.

4 Li D, Liu M, Tao TQ, Song DD, Liu XH, Shi DZ: Panax quinquefolium saponin attenuates cardiomyocyte apoptosis and opening of the mitochondrial permeability transition pore in a rat model of ischemia/ reperfusion. Cell Physiol Biochem 2014;34:1413-1426.

5 Littlejohns B, Lin H, Angelini GD, Halestrap AP, Suleiman MS: Switching back to normal diet following highfat diet feeding reduces cardiac vulnerability to ischaemia and reperfusion injury. Cell Physiol Biochem 2014;34:1090-1100.

6 Yu D, Li M, Tian Y, Liu J, Shang J: Luteolin inhibits ros-activated mapk pathway in myocardial ischemia/ reperfusion injury. Life Sci 2015;122:15-25.

7 Zhang X, Liang X, Lin X, Zhang S, Huang Z, Chen C, Guo Y, Xuan F, Xu X, Huang R: Mechanism of the protective effect of yulangsan flavonoid on myocardial ischemia/reperfusion injury in rats. Cell Physiol Biochem 2014;34:1050-1062.

8 Luo T, Chen B, Zhao Z, He N, Zeng Z, Wu B, Fukushima Y, Dai M, Huang Q, Xu D, Bin J, Kitakaze M, Liao Y: Histamine h2 receptor activation exacerbates myocardial ischemia/reperfusion injury by disturbing mitochondrial and endothelial function. Basic Res Cardiol 2013;108:342.

9 Ma HJ, Li Q, Guan Y, Shi M, Yang J, Li DP, Zhang Y: Chronic intermittent hypobaric hypoxia ameliorates ischemia/reperfusion-induced calcium overload in heart via na/ca2+ exchanger in developing rats. Cell Physiol Biochem 2014;34:313-324.

10 Niu J, Azfer A, Zhelyabovska O, Fatma S, Kolattukudy PE: Monocyte chemotactic protein (mcp)-1 promotes angiogenesis via a novel transcription factor, mcp-1-induced protein (mcpip). J Biol Chem 2008;283:14542-14551. 


\section{Cellular Physiology Cell Physiol Biochem 2015;37:577-591 \begin{tabular}{l|l|l} 
DOI: 10.1159/000430378 & (C) 2015 S. Karger AG, Basel
\end{tabular} and Biochemistry Published online: September 01, $2015 \quad$ www.karger.com/cpb \\ Zhu et al.: The Role of MCPIP1 in HUVECs Subjected to I/R}

11 Calvillo L, Vanoli E, Andreoli E, Besana A, Omodeo E, Gnecchi M, Zerbi P, Vago G, Busca G, Schwartz PJ: Vagal stimulation, through its nicotinic action, limits infarct size and the inflammatory response to myocardial ischemia and reperfusion. J Cardiovasc Pharmacol 2011;58:500-507.

12 Hesse AR, Levent E, Zieseniss A, Tiburcy M, Zimmermann WH, Katschinski DM: Lights on for hif-1alpha: Genetically enhanced mouse cardiomyocytes for heart tissue imaging. Cell Physiol Biochem 2014;34:455462.

13 Zhu Y, Wu J, Yuan SY: Mct1 and mct4 expression during myocardial ischemic-reperfusion injury in the isolated rat heart. Cell Physiol Biochem 2013;32:663-674.

14 Charo IF, Taubman MB: Chemokines in the pathogenesis of vascular disease. Circ Res 2004;95:858-866.

15 Ito WD, Arras M, Winkler B, Scholz D, Schaper J, Schaper W: Monocyte chemotactic protein-1 increases collateral and peripheral conductance after femoral artery occlusion. Circ Res 1997;80:829-837.

16 Carmeliet P: Angiogenesis in life, disease and medicine. Nature 2005;438:932-936.

17 Peters K, Troyer D, Kummer S, Kirkpatrick CJ, Rauterberg J: Apoptosis causes lumen formation during angiogenesis in vitro. Microvasc Res 2002;64:334-338.

18 Tertemiz F, Kayisli UA, Arici A, Demir R: Apoptosis contributes to vascular lumen formation and vascular branching in human placental vasculogenesis. Biol Reprod 2005;72:727-735.

19 Duval H, Harris M, Li J, Johnson N, Print C: New insights into the function and regulation of endothelial cell apoptosis. Angiogenesis 2003;6:171-183.

20 Voskuil M, van Royen N, Hoefer IE, Seidler R, Guth BD, Bode C, Schaper W, Piek JJ, Buschmann IR: Modulation of collateral artery growth in a porcine hindlimb ligation model using mcp-1. Am J Physiol Heart Circ Physiol 2003;284:H1422-1428.

21 Deindl E, Schaper W: The art of arteriogenesis. Cell Biochem Biophys 2005;43:1-15.

22 Moldovan NI, Goldschmidt-Clermont PJ, Parker-Thornburg J, Shapiro SD, Kolattukudy PE: Contribution of monocytes/macrophages to compensatory neovascularization: The drilling of metalloelastase-positive tunnels in ischemic myocardium. Circ Res 2000;87:378-384.

23 Salcedo R, Ponce ML, Young HA, Wasserman K, Ward JM, Kleinman HK, Oppenheim JJ, Murphy WJ: Human endothelial cells express ccr2 and respond to mcp-1: Direct role of mcp-1 in angiogenesis and tumor progression. Blood 2000;96:34-40.

24 Hong KH, Ryu J, Han KH: Monocyte chemoattractant protein-1-induced angiogenesis is mediated by vascular endothelial growth factor-a. Blood 2005;105:1405-1407.

25 Zhou L, Azfer A, Niu J, Graham S, Choudhury M, Adamski FM, Younce C, Binkley PF, Kolattukudy PE: Monocyte chemoattractant protein-1 induces a novel transcription factor that causes cardiac myocyte apoptosis and ventricular dysfunction. Circ Res 2006;98:1177-1185.

26 Bidzhekov K, Zernecke A, Weber C: Mcp-1 induces a novel transcription factor with proapoptotic activity. Circ Res 2006;98:1107-1109.

27 Vrotsos EG, Kolattukudy PE, Sugaya K: Mcp-1 involvement in glial differentiation of neuroprogenitor cells through app signaling. Brain Res Bull 2009;79:97-103.

28 Liang J, Wang J, Azfer A, Song W, Tromp G, Kolattukudy PE, Fu M: A novel ccch-zinc finger protein family regulates proinflammatory activation of macrophages. J Biol Chem 2008;283:6337-6346.

29 Han L, Xu C, Jiang C, Li H, Zhang W, Zhao Y, Zhang L, Zhang Y, Zhao W, Yang B: Effects of polyamines on apoptosis induced by simulated ischemia/reperfusion injury in cultured neonatal rat cardiomyocytes. Cell Biol Int 2007;31:1345-1352.

30 Yan L, Zhu T, Sun T, Wang L, Pan S, Tao Z, Yang Z, Cao K: Activation of calcium-sensing receptors is associated with apoptosis in a model of simulated cardiomyocytes ischemia/reperfusion. J Biomed Res 2010;24:301-307.

31 Yan L, Zhu TB, Wang LS, Pan SY, Tao ZX, Yang Z, Cao K, Huang J: Inhibitory effect of hepatocyte growth factor on cardiomyocytes apoptosis is partly related to reduced calcium sensing receptor expression during a model of simulated ischemia/reperfusion. Mol Biol Rep 2011;38:2695-2701.

32 Van Horn K, Toth C: Evaluation of the anaeropack campylo system for growth of microaerophilic bacteria. J Clin Microbiol 1999;37:2376-2377.

33 Lo LW, Koch CJ, Wilson DF: Calibration of oxygen-dependent quenching of the phosphorescence of pdmeso-tetra (4-carboxyphenyl) porphine: A phosphor with general application for measuring oxygen concentration in biological systems. Anal Biochem 1996;236:153-160. 


\section{Cellular Physiology Cell Physiol Biochem 2015;37:577-591 \begin{tabular}{l|l|l}
\hline DOI: 10.1159/000430378 & (C) 2015 S. Karger AG, Basel
\end{tabular} www.karger.com/cpb \\ Zhu et al.: The Role of MCPIP1 in HUVECs Subjected to I/R}

34 Chao J, Wood JG, Blanco VG, Gonzalez NC: The systemic inflammation of alveolar hypoxia is initiated by alveolar macrophage-borne mediator(s). Am J Respir Cell Mol Biol 2009;41:573-582.

35 Yao H, Ma R, Yang L, Hu G, Chen X, Duan M, Kook Y, Niu F, Liao K, Fu M, Kolattukudy P, Buch S: Mir-9 promotes microglial activation by targeting mcpip1. Nat Commun 2014;5:4386.

36 Liu X, Fang S, Liu H, Wang X, Dai X, Yin Q, Yun T, Wang W, Zhang Y, Liao H, Zhang W, Yao H, Chao J: Role of human pulmonary fibroblast-derived mcp-1 in cell activation and migration in experimental silicosis. Toxicol Appl Pharmacol DOI: 10.1016/j.taap.2015.07.002.

37 Chao J, Pena T, Heimann DG, Hansen C, Doyle DA, Yanala UR, Guenther TM, Carlson MA: Expression of green fluorescent protein in human foreskin fibroblasts for use in $2 \mathrm{~d}$ and $3 \mathrm{~d}$ culture models. Wound Repair Regen 2014;22:134-140.

38 Carlson MA, Longaker MT, Thompson JS: Modulation of fak, akt, and p53 by stress release of the fibroblastpopulated collagen matrix. J Surg Res 2004;120:171-177.

39 Grinnell F, Zhu M, Carlson MA, Abrams JM: Release of mechanical tension triggers apoptosis of human fibroblasts in a model of regressing granulation tissue. Exp Cell Res 1999;248:608-619.

40 Carlson MA, Prall AK, Gums JJ: Rna interference in human foreskin fibroblasts within the three-dimensional collagen matrix. Mol Cell Biochem 2007;306:123-132.

41 Grinnell F, Rocha LB, Iucu C, Rhee S, Jiang H: Nested collagen matrices: A new model to study migration of human fibroblast populations in three dimensions. Exp Cell Res 2006;312:86-94.

42 Miron-Mendoza M, Seemann J, Grinnell F: The differential regulation of cell motile activity through matrix stiffness and porosity in three dimensional collagen matrices. Biomaterials 2010;31:6425-6435.

43 Peng F, Dhillon N, Callen S, Yao H, Bokhari S, Zhu X, Baydoun HH, Buch S: Platelet-derived growth factor protects neurons against gp120-mediated toxicity. J Neurovirol 2008;14:62-72.

44 Yao H, Peng F, Dhillon N, Callen S, Bokhari S, Stehno-Bittel L, Ahmad SO, Wang JQ Buch S: Involvement of trpc channels in ccl2-mediated neuroprotection against tat toxicity. J Neurosci 2009;29:1657-1669.

45 Frangogiannis NG, Dewald O, Xia Y, Ren G, Haudek S, Leucker T, Kraemer D, Taffet G, Rollins BJ, Entman ML: Critical role of monocyte chemoattractant protein-1/cc chemokine ligand 2 in the pathogenesis of ischemic cardiomyopathy. Circulation 2007;115:584-592.

46 Zhang J, Wang C, Yu S, Luo Z, Chen Y, Liu Q, Hua F, Xu G, Yu P: Sevoflurane postconditioning protects rat hearts against ischemia-reperfusion injury via the activation of pi3k/akt/mtor signaling. Sci Rep 2014;4:7317.

47 Li HY, Cui XY, Wu W, Yu FY, Yao HR, Liu Q, Song EW, Chen JQ: Pyk2 and src mediate signaling to ccl18induced breast cancer metastasis. J Cell Biochem 2014;115:596-603.

48 Basile JR, Afkhami T, Gutkind JS: Semaphorin 4d/plexin-b1 induces endothelial cell migration through the activation of pyk2, src, and the phosphatidylinositol 3-kinase-akt pathway. Mol Cell Biol 2005;25:68896898.

49 Fischer RS, Gardel M, Ma X, Adelstein RS, Waterman CM: Local cortical tension by myosin ii guides 3d endothelial cell branching. Curr Biol 2009;19:260-265.

50 Aizawa Y, Wylie R, Shoichet M: Endothelial cell guidance in 3d patterned scaffolds. Adv Mater 2010;22:4831-4835.

51 Ibanez B, Heusch G, Ovize M, Van de Werf F: Evolving therapies for myocardial ischemia/reperfusion injury. J Am Coll Cardiol 2015;65:1454-1471.

52 Pfeffer MA, Braunwald E: Ventricular remodeling after myocardial infarction. Experimental observations and clinical implications. Circulation 1990;81:1161-1172.

53 Frangogiannis NG, Smith CW, Entman ML: The inflammatory response in myocardial infarction. Cardiovasc Res 2002;53:31-47.

54 Shimizu T, Okamoto H, Chiba S, Matsui Y, Sugawara T, Akino M, Nan J, Kumamoto H, Onozuka H, Mikami T, Kitabatake A: Vegf-mediated angiogenesis is impaired by angiotensin type 1 receptor blockade in cardiomyopathic hamster hearts. Cardiovasc Res 2003;58:203-212.

55 Yang B, Yang J, Bai J, Pu P, Liu J, Wang F, Ruan B: Suv39h1 protects from myocardial ischemia-reperfusion injury in diabetic rats. Cell Physiol Biochem 2014;33:1176-1185.

56 Li Q Wang F, Zhang YM, Zhou JJ, Zhang Y: Activation of cannabinoid type 2 receptor by jwh133 protects heart against ischemia/reperfusion-induced apoptosis. Cell Physiol Biochem 2013;31:693-702.

57 Chopra V, Dinh TV, Hannigan EV: Three-dimensional endothelial-tumor epithelial cell interactions in human cervical cancers. In Vitro Cell Dev Biol Anim 1997;33:432-442. 


\section{Cellular Physiology Cell Physiol Biochem 2015;37:577-591 \begin{tabular}{l|l|l|}
\hline DOI: 10.1159/000430378 & (0) 2015 S. Karger AG, Basel
\end{tabular} \\ Zhu et al.: The Role of MCPIP1 in HUVECs Subjected to I/R}

58 Merwin JR, Anderson JM, Kocher O, Van Itallie CM, Madri JA: Transforming growth factor beta 1 modulates extracellular matrix organization and cell-cell junctional complex formation during in vitro angiogenesis. J Cell Physiol 1990;142:117-128.

59 Carlson MA, Longaker MT: The fibroblast-populated collagen matrix as a model of wound healing: A review of the evidence. Wound Rep Regen 2004;12:134-147.

60 Grinnell F, Petroll WM: Cell motility and mechanics in three-dimensional collagen matrices. Annu Rev Cell Dev Biol 2010;26:335-361.

61 Harunaga JS, Yamada KM: Cell-matrix adhesions in 3d. Matrix Biol 2011;30:363-368.

62 Kim B-S, Park I-K, Hoshiba T, Jiang H-L, Choi Y-J, Akaike T, Cho C-S: Design of artificial extracellular matrices for tissue engineering. Prog Polymer Sci 2011;36:238-268.

63 Gallagher PJ, Herring BP, Stull JT: Myosin light chain kinases. J Muscle Res Cell Motil 1997;18:1-16.

64 Du QS, Ren XR, Xie Y, Wang Q, Mei L, Xiong WC: Inhibition of pyk2-induced actin cytoskeleton reorganization, pyk2 autophosphorylation and focal adhesion targeting by fak. J Cell Sci 2001;114:29772987.

65 Lakkakorpi PT, Bett AJ, Lipfert L, Rodan GA, Duong le T: Pyk2 autophosphorylation, but not kinase activity, is necessary for adhesion-induced association with c-src, osteoclast spreading, and bone resorption. J Biol Chem 2003;278:11502-11512.

66 Donato AJ, Gano LB, Eskurza I, Silver AE, Gates PE, Jablonski K, Seals DR: Vascular endothelial dysfunction with aging: Endothelin-1 and endothelial nitric oxide synthase. Am J Physiol Heart Circ Physiol 2009;297:H425-432. 